Document downloaded from:

http://hdl.handle.net/10251/40214

This paper must be cited as:

Paredes Arquiola, J.; Solera Solera, A.; Martinez-Capel, F.; Momblanch Benavent, A.; Andreu Álvarez, J. (2014). Integrating water management, habitat modelling and water quality at basin scale environmental flow assessment - Tormes River (Spain). Hydrological Sciences Journal. 59(3-4):878-889. doi:10.1080/02626667.2013.821573.

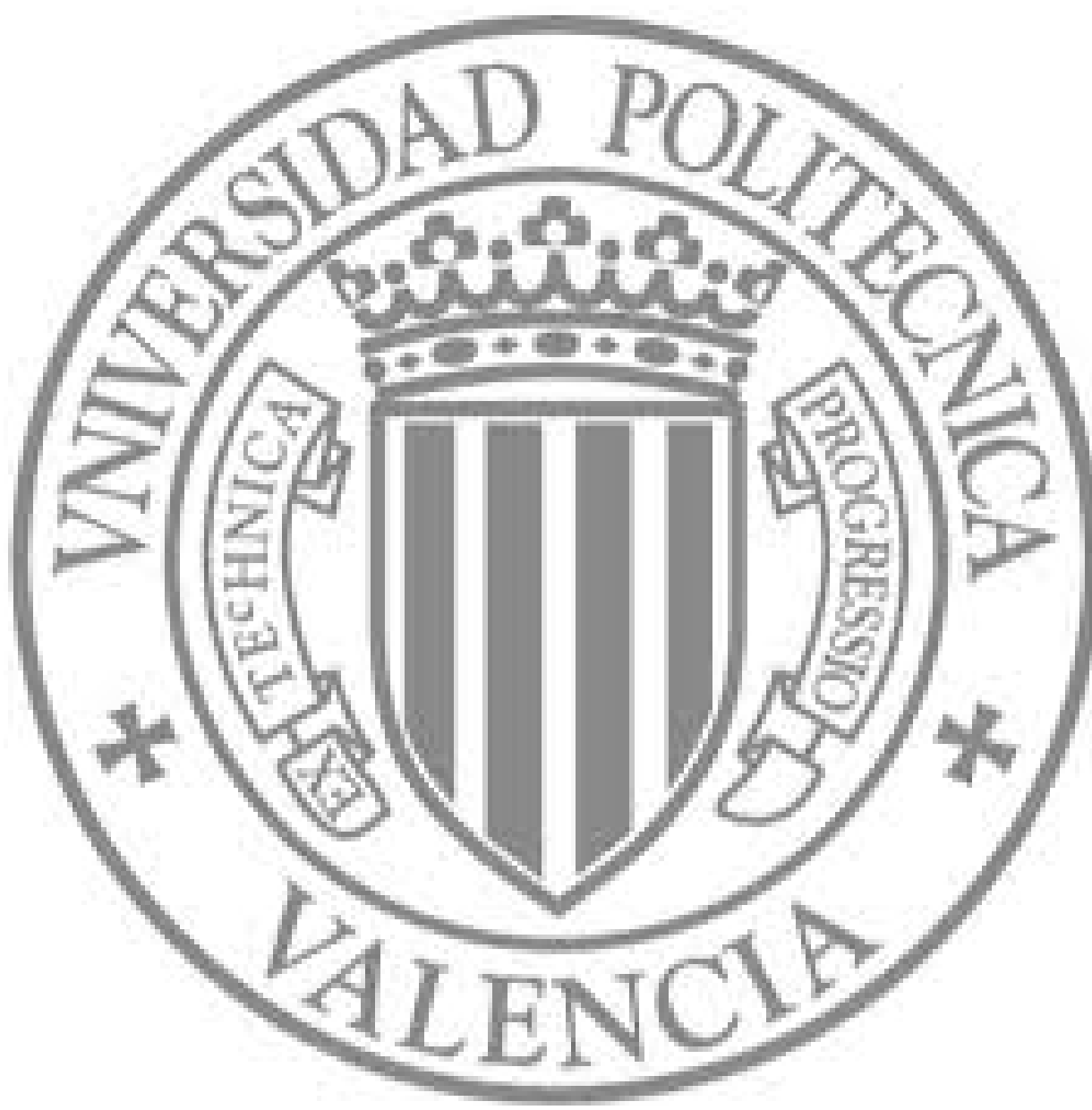

The final publication is available at

http://dx.doi.org/10.1080/02626667.2013.821573

Copyright Taylor \& Francis: STM, Behavioural Science and Public Health Titles 


\title{
Integrating water management, habitat modelling and water quality at basin scale and environmental flow assessment:case study of Tormes River, Spain
}

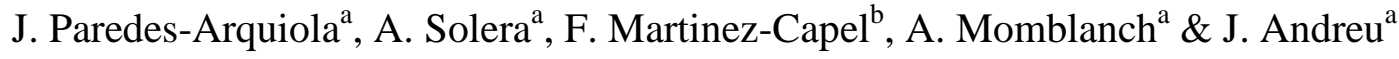 \\ a Instituto de Ingeniería del Agua y Medio Ambiente, Universitat Politècnica de València, Valencia, \\ Spain \\ ${ }^{\mathrm{b}}$ Institut d'Investigació per a la Gestió Integrada de Zones Costaneres, Universitat Politècnica de \\ València, Valencia, Spain \\ jparedea@hma.upv.es; asolera@upvnet.upv.es; fmcapel@dihma.upv.es; anmombe@upv.es; \\ ximoand@upvnet.upv.es
}

Received 26 September 2012; accepted 26 March 2013; open for discussion until 26 May 2013

\begin{abstract}
Citation Paredes-Arquiola, J., Solera, A., Martinez-Capel, F., Momblanch, A., and Andreu, J. 2013. Integrating water management, habitat modelling and water quality at basin scale environmental flow assessment - Tormes River (Spain). Hydrological Science Journal,
\end{abstract}

\begin{abstract}
Multidisciplinary models are useful for integrating different disciplines when addressing water planning and management problems. We combine water resources management, water quality and habitat analysis tools that were developed with the Decision Support System AQUATOOL at a basin scale. The water management model solves the allocation problem through network flow optimisation and considers the environmental flows in some river stretches. Once volumes and flows are estimated, the water quality model is applied. Furthermore, the flows are evaluated from an ecological perspective by using time series of aquatic species habitat indicators. This approach was applied in the Tormes River Water System, where agricultural demands jeopardise the environmental needs of the river ecosystem. Additionally, water quality problems in the lower part of the river result from wastewater loading and agricultural pollution. Our methodological framework can be used to define water management rules that maintain water supply, aquatic ecosystem and water quality legal standards. The integration of ecological and water management criteria in a software platform with objective criteria and heuristic optimisation procedures allows for the realistic assessment and application of environmental flows. Here, we improve the general methodological framework by assessing the hydrological alteration of selected environmental flow regime scenarios.
\end{abstract}

Key words Water resources management; Environmental flows; Operation rules; AQUATOOL; Water quality; Habitat Time Series; Decision making.

\section{INTRODUCTION}

Human population numbers and activities increasingly pressure aquatic environments, especially freshwater ecosystems. As the demand for water resources increases, it is becoming apparent that the water supply is insufficient for meeting all needs without tough management decisions (Gleick 1993). Increased water use, especially for agriculture, reduces river flow. In addition, water quality is impaired by pollution. This situation will likely worsen with the predicted consequences of climate change, such as the reduction of resources in Mediterranean basins (Solomon et al. 2007). Moreover, new water policies around the world are demanding more integrated, participatory, sustainable, efficient, and equitable water resource planning and management (UNCED 1992, NRC 2000, EC 2000). The obligatory Water Framework Directive (WFD) (EC 2000) defines guidelines about the conditions that are needed to achieve good ecological status in different water bodies. To define good ecological 
status, methods to improve environmental conditions, ecological flows, physical aspects and other considerations should be established. This task requires obtaining water allocation and environmental flow definitions from decision makers.

These considerations introduce more complexity into complex integrated water resource management tasks. To make good decisions, the information must be managed and analysed by considering feasible alternatives, their impacts on multiple objectives, the trade-offs among them, and the associated risks. Sound science, technology, and expertise are necessary to elaborate on and analyse such information (Andreu et al. 2008). Scientists often complain that their input is ignored by decision makers. Meanwhile, decision makers have complained that the critical information needed for making decisions is often not readily available, accessible or in a usable form (Liu et al. 2008). If there is no coordination between the water managers and the river basin authorities, the generation of environmental flows for biodiversity without considering real water management alternatives and public consultation could lead to social and legal conflicts. These conflicts could prevent present and future flow regulation changes (Paredes-Arquiola et al. 2011).

Water resource allocation decisions impact all of the basin uses, including the environmental uses. A key step in this allocation process is the setting of environmental flows. An environmental flow is the flow regime for a river that maintains the desired ecological conditions. It includes aspects of physical, chemical and biological components and their interactions (Acreman 2005). Therefore, the use of integrative models that account for different whole water system aspects, especially water resource sharing, water quality and environmental considerations, are increasingly necessary. To coordinate and optimise the environmental flows at the river network scale, a decision support system (DSS) can be used to assess the effects of different environmental flows on the in-stream flow, the reliability of water supply demands, hydropower production and aquatic habitats (Paredes-Arquiola et al. 2011).

In this paper, a methodological framework (Paredes-Arquiola et al. 2011) that is comprised of three coordinated models is used to integrate aspects of water allocation, water quality and environmental requirements. These three models are part of the AQUATOOL Decision Support System (Andreu et al. 1996) for water planning and management. This approach is applied to the Tormes River, a tributary of the Duero River, where the three previously mentioned problems coexist. The use of these models together integrates water quality into decision making and provides objective criteria for distributing the water resources based on the demands of the watershed and the environmental uses. Here, we define an operation rule (OR) for a system that balances the supply deficit with the minimum environmental flow impact within Spain's present legal framework (MARM 2008). In addition, the general methodological framework was improved by implementing a hydrological alteration assessment to evaluate the environmental flow regime scenarios.

\section{MATERIAL AND METHODS}

The proposed methodology is based on the concatenation of a Water Allocation Model (WAM), a model for water quality and a model for generating Habitat Time Series (HTS). This procedure integrates three essential components for defining the distribution of resources and environmental flow regimes in a basin or water system, including water quantity, water quality, and habitat suitability for aquatic species. For the evaluation of such components, we use the DSS AQUATOOL, which is widely applied for the development of RBMPs and other water plans in Spain. This 
methodological framework was generally defined and applied in the entire Duero River Basin (Paredes-Arquiola et al 2011). Now, water quality and hydrological alteration are incorporated into this method. The first step in the procedure, Step 0, includes the development, calibration and validation of the three models in the river network.

The WAM was developed with the SIMGES program (Andreu et al. 2007), which is similar to the SIM V family (TDWR 1982). These models all solve the water allocation and management system problems by optimising the flows at the network elements. The GESCAL program (Paredes et al. 2004) is widely applied in Spain to develop water quality models of rivers, lakes/reservoirs or complete water systems (Paredes et al. 2010, Paredes-Arquiola et al. 2010). Within this program, the flows within water bodies, the reservoir volumes and information about the chemical concentrations in the natural inflows, diffuse pollution, and point loads are used as inputs. The third model is used to assess habitat suitability. One of the most commonly used methods to estimate environmental flows throughout the world is the Physical Habitat Simulation model (PHABSIM) (Bovee et al. 1998). The PHABSIM relates the physical habitat and river flow with curves that are commonly referred to as Weighted Usable Area-flow (WUA-flow) curves. Therefore, it is possible to develop a HTS that is related to the proposed management by using the WUA-flow curves and the WAM optimised flows (Milhous et al. 1990, Capra et al. 1995, Parasiewicz 2008). This time series show the habitat indicator, the WUA, for the considered species as the river flow varies due to changing hydrological conditions and the system management. The CAUDECO program in AQUATOOL DSS provides HTS for each available WUA-flow curve and is similar to the TSLIB tool (Milhous et al. 1990).

In Step 1, the effects of establishing new environmental flows on the other variables of the system are estimated. Next, a set of simulations are performed with the three coupled models at different environmental flow levels within a pre-defined range. Multiple tests are made by combining the environmental flow levels at the four points. Figure 1 shows a simplification of this procedure. For each simulation of the three models, several Simulation-Indicators of the water system status are generated to assess the systems dynamic behaviour. The Simulation-Indicators in this stage of the study include the percentage of agricultural demand deficits as an indicator of water management, the dissolved oxygen and ammonium concentrations as indicators of water quality, and the HTS of the most affected species as an ecological indicator. After all of these simulations, it is possible to conduct an analysis of the trade-offs among the different environmental flow and water management alternatives. In this case, the Tradeoff-Indicators include the following: the maximum percentage of the total agricultural water demand deficit, the maximum ammonium concentration and the minimum dissolved oxygen concentration during the simulation period and the percentage to the maximum WUA that corresponds to the 80th percentile of the HTS for the most affected species. The last indicator represents the WUA, which is exceeded $80 \%$ of the time during the simulation period (Lafayette and Loucks 2003).

The DSS AQUATOOL has a long history of application in Spain. In particular, SIMGES has been implemented in almost all of the Spanish basins by public administration and consulting firms over the past 20 years to develop RBMPs and other water resource system management studies. The presented methodology establishes criteria for the joint analysis of various system status indicators. The time scale and the studied components are only one part of the entire water system problem, but are the main issues. At present, this methodology works for a monthly 
time scale and takes into account the main related processes. The hydrological alteration assessment is used to evaluate management scenarios and considers flow variability and magnitude for medium, low and high flows.

It is widely recognised that the hydrologic regime is the primary driver of freshwater ecosystems and structures the physical habitat template (Poff et al. 1997). Consequently, several methodological frameworks have used the natural flow regime analysis as the baseline condition for comparison with the environmental flow regime under different management scenarios (e.g., IFIM; Bovee et al. 1982) and for hydrological alteration assessments (e.g., ELOHA, Poff et al. 2010). In this article, we provide a step that improves the methodological framework (Paredes-Arquiola et al. 2011) by implementing a hydrological alteration assessment of the environmental flow regime scenarios.

\section{STUDY AREA: TORMES RIVER BASIN}

The Tormes River Water System (TRWS) is a subsystem of the Duero River Basin that spans from the source of the Tormes River basin to upstream of the Almendra reservoir. This reservoir is located at the confluence of the Tormes River and the Duero River. Figure 3 shows a simplified water resources system diagram that includes its main elements. There are several reservoirs in the system, but only the Santa Teresa reservoir has a hyper annual regulatory capacity (maximum storage 496 $\mathrm{hm}^{3}$ ). The average watershed resources amount to approximately $1230 \mathrm{hm}^{3} /$ year. However, during the period analysed, watershed resources only amounted to 900 $\mathrm{hm}^{3} /$ year. The estimated consumption for the 2015 planning horizon is $540 \mathrm{hm}^{3} /$ year, which accounts for $60 \%$ of the annual resources. This small difference between demand and available resources causes a water shortage during drought periods despite the Santa Teresa reservoir regulations. The TRWS is a multipurpose water supply system in which agricultural, urban and hydropower account for the majority of water demand. Aquaculture and industrial demands are less important.

There are several gauging sites in the Tormes River. Long flow datasets were updated until 2007, and data regarding the main pollutants between 1996 and 2009 (monthly basis) are provided by the Duero River Basin Authority (DRBA) water quality monitoring network. The water quality is generally good in most river segments. Upstream of the Santa Teresa dam, the effects of human activities on the water are negligible. Consequently, the water is clear with less than $60 \mu \mathrm{s} / \mathrm{cm}$ conductivity, less than $2 \mathrm{mgNO}_{3} / \mathrm{L}$ nitrates, and less than $0.5 \mathrm{mgNH} / 4$ ammonium. Downstream, the human impacts and activities are slowly growing. In the middle part of the river, from the Santa Teresa dam to the Villagonzalo dam, the major pressures come from diffuse pollution from agricultural activities and urban discharges. The water quality is slightly affected by these pressures. Some environmental pressures are concentrated downstream of the Villagonzalo dam, including several urban and industrial discharges from the city of Salamanca. These environmental pressures modify the physical properties of the water and the chemical concentrations in the water from downstream of the Villagonzalo dam to the Water Quality Site (WQS) at Contiensa. In this section of the river, the water quality worsens and strongly depends on the river flow. In the summer, dissolved oxygen decreases to less than $6 \mathrm{mg} / \mathrm{L}$ or 4 $\mathrm{mg} / \mathrm{L}$ in dry summers. Thus, the segment between Salamanca city and the Contiensa WQS is considered the most critical in the TRWS. The river segments selected for this study (regarding their relevance in the aforementioned problems) are located near the Contiensa WQS (Point 4) and just downstream of the Villagonzalo dam (Point 3). 
Two more points were analysed to obtain a global view of the river system performance, one between the Santa Teresa and Villagonzalo reservoirs (Point 2) and another upstream of the Santa Teresa reservoir (Point 1). These four points are identified in figure 3.

In the Duero River Basin Management Plan (RBMP) of the 90s, the present environmental flows were defined as $10 \%$ of the mean annual inflow. Currently, it is necessary to improve the new RBMP environmental flows to achieve good ecological status in water bodies. The extensive environmental flow studies, including habitat suitability models and habitat simulation, began in Spain in 2005 (e.g., MartinezCapel et al. 2006). These studies included habitat selection by fish, which permitted the application of several technical methods.

In the TRWS, previous studies defined the WUA-flow curves for different size classes of the most relevant fish species in the river (García de Jalón and Lurueña 2000, INFRAECO 2009). The WUA-flow curves at point 4 were obtained in a river reach at Baños de Ledesma (Salamanca), where the fish species were Luciobarbus bocagei, Pseudochondrostoma duriense and Squalius carolitertii. For the first species there were three habitat suitability curve (HSC) size classes. For the other two species there were only two HSC size classes. Site 4 belongs to the large Mediterranean mainstem ecotype. At points 2 and 3, we applied the nearest WUA-flow curves that were developed in a river reach at Villagonzalo de Tormes (Salamanca). Here, the fish species were Salmo trutta fario, Luciobarbus bocagei, Achondrostoma arcasii, Pseudochondrostoma duriense and Squalius carolitertii. The HSC for the first species (brown trout) were available in three size classes and for spawning. There were 3 HSC by size class for Luciobarbus b., one for Achondrostoma a. and two for the last two species. Finally, the curves for brown trout were applied at site 1 (García de Jalón and Lurueña 2000).

An important advantage of this methodology is the optimisation of actual water management to produce the best feasible environmental flows in realistic water management scenarios with water right constraints in the river basin. The models discussed here are the result of several years of collaboration with the DRBA Office of Water Planning and the RBMP consultancy company. These models are being used for decision making in the development of the next RBMP according to the WFD. Both models, the quantity and quality, were calibrated and validated with available data from stations of the DRBA.

The SIMGES model includes the main TRWS elements and was calibrated according to the present system management (the status before the definition of the new environmental flows, PRESENT scenario). The environmental flows are imposed as minimum flows in the segments (arcs) of the model and (according to the Spanish law) they have higher priority than any demand other than urban supply. The runoff data were available from 1940 to 2006. Thus, the model was calibrated with the last ten years of available data. The simulations from October 1996 to September 2009 are included because this is a critical period that is related to drought events.

The GESCAL model in the TRWS was developed to represent the evolution of conductivity, dissolved oxygen, BOD5, phosphorous, ammonium, organic nitrogen and nitrates. Input concentrations were obtained from the water quality sites of the DRBA's monitoring network. Moreover, the DRBA monitors the effluents of the main waste water treatment plants, which was also incorporated into the model. In the low part of the river, the sensitivity analysis of the model indicates a high dependency of concentration on the streamflow downstream of the Villagonzalo dam. 
The previously mentioned studies provided the WUA-flow curves and the recommended range of flows for the new environmental flows based on the Spanish legal framework. Several simulations were conducted with different environmental flow regimes. The most relevant scenarios, which are separately analysed in this paper, include the following: the PRESENT scenario with no new environmental flow implementation, the QECO-OPT scenario that in which the environmental flows are set at the maximum level at every studied point, and the OR scenario which sets the maximum environmental flows but applies an OR for drought periods. The simulation scheme is shown in figure 4.

The hydrological alteration was specifically assessed for two scenarios, the PRESENT and the OR. The monthly flow data resulting from the SIMGES optimisation were analysed at point 4 (Contiensa), which was assumed to have the maximum hydrological alteration in the study area. A group of hydrological indices describing either monthly or annual characteristics (Table 1) were selected, which represent the wide range of ecologically relevant flow statistics that were applied previously in Mediterranean rivers (Belmar et al. 2011).

\section{RESULTS AND DISCUSSION}

\section{Assessment of the relationships between the minimum environmental flows and the system state indicators}

Based on legislation, the new environmental flow proposal habitat studies provided a potential range of environmental flows at each system point. From the set of performed simulations, the obtained results covered three major components and were treated and analysed together. Figure 5 shows the Simulation-Indicators at point 4 over the simulation period without defining any new environmental flows in the system (PRESENT). In this scenario, the deficits of demand are 30 and $60 \%$ of the monthly demand and occur during the summers of 1997 and 1998, respectively. Thus, an annual deficit of demand of $9.87 \%$ occurred, which is below the limit established by Spanish legislation. In terms of habitat, Luciobarbus b. is the most affected species. That is because in September, October and November water is not released from the reservoirs to supply the irrigation demands. In addition, the simulation model tends to store water in the Santa Teresa reservoir for the future, which reduces river flows. Nevertheless, in many months the usable habitat is close to $100 \%$ of the maximum. Thus, the river flows potentially provide very good habitats for these fish. However, in most years, their potential habitat is reduced dramatically to less than $50 \%$ in September, October and November. Additionally, the water quality is poor during these months due to the reduced flow. For example, ammonium concentrations reach more than $6 \mathrm{mgNH}_{4} / \mathrm{L}$ and dissolved oxygen levels drop to $1 \mathrm{mg} / \mathrm{L}$. In 1998, the most critical year, dissolved oxygen concentrations were less than $1 \mathrm{mg} / \mathrm{L}$. Thus, aquatic life would not occur at any WUA level.

In Figure 6, the Simulation-Indicators are shown at point 4 for the QECO-OPT scenario. The results for this scenario show the impacts on the demands reliability, resilience and vulnerability. The reliability decreases due to the increasing number of deficit months. This increase implies an increment of consecutive deficit months. In addition, the deficits raise and impact the vulnerability of the agricultural demands. For example, in this scenario supply deficits occur in a non-deficit year (2000) in the PRESENT scenario. During the summer months, the deficits reach $46.47 \%$ of the required annual agricultural demand. Although this value does not meet the minimum 
legal supply level (50\% of the MADf), it is very close. The degradation of the demands reliability benefits the habitat conditions and water quality. For example, in this scenario, dissolved oxygen concentrations are greater than $5.8 \mathrm{mg} / \mathrm{L}$ in most summers and are close to $5.5 \mathrm{mg} / \mathrm{L}$ at critical time points. In addition, maximum ammonium concentrations of $1 \mathrm{mg} / \mathrm{L}$ occur, which is considered as the acceptable threshold for all types of aquatic life. The habitat conditions in the QECO-OPT scenario are excellent and always exceed $70 \%$ of the maximum usable habitat.

A set of possible scenarios (intermediate scenarios) that combine different environmental flow levels at different basin points can be established between the two figures. To summarise the possible effects of these environmental flows, several simulations were performed by increasing the environmental flows from 0 to $100 \%$ of the maximum at increments of $10 \%$. Because point 4 is critical in the TRWS, decision making should be based on the analysis of its results. Figure 7 shows the TradeoffIndicators trends at point 4 . Remarkably, the $80 \%$ percentile indicator of habitat remains constant until the flow rate reaches level $3\left(1.20 \mathrm{~m}^{3} / \mathrm{s}\right)$. Thereafter, it begins to increase linearly. In addition, the maximum ammonium concentrations strongly decrease at the first environmental flow step. This decrease indicates that an environmental flow at or above step 3 should be chosen. According to the MADf for the irrigation demands, small incremental changes occur in the first steps. However, this indicator rapidly increases as the flow rate increases from $3.6 \mathrm{~m}^{3} / \mathrm{s}$. This type of figure can help decision makers and stakeholders in the negotiation and establishment of environmental flows that maintain equilibrium among the systems essential components.

\section{Managing the resources: Operation Rule}

Arguably, the QECO-OPT scenario implies that a loss of agricultural water demand reliability occurs, which could lead to social and legal problems. Based on this situation, the objective is to maintain a high environmental flow during wet and normal years so that in drought years the impact is not fully absorbed by the agricultural demands. This can be achieved by reducing the environmental requirements and the water quality levels. Therefore, an OR should be defined to reduce the releases from Villagonzalo dam. This OR will decrease the environmental flows in the final stretch when the Santa Teresa reservoir inflows are below a threshold. These types of ORs are commonly used in water system management and are easily understood by managers and stakeholders. However, the problem is complex because the inflow threshold should be defined for each month. An iterative heuristic optimisation process was used to find the minimum threshold and the minimum environmental flow reduction rates that complied with the agricultural reliability legal demands. With this approach, an optimal OR was obtained. The OR is defined as follows: "when the monthly inflows into the Santa Teresa reservoir in the last four months are below the 85th percentile of the historical data, then the environmental flow at point 4 is reduced from 6 to $3 \mathrm{~m}^{3} / \mathrm{s}$ ". With this method, we try to maintain an optimal environmental situation, where the environmental requirements are only reduced during drought periods.

Figure 8 shows the Simulation-Indicators that were obtained from the new simulation scenario, OR. Relative to the QECO-OPT scenario, the deficit of demands was reduced to a level that meets the water law reliability (see figure 6). In terms of HTS, many months remained at $100 \%$. However, in some of the months in drier years 
the usable habitat is reduced to $60 \%$ of the maximum. This value only falls below the threshold of $60 \%$ in August and September of 2000. This is acceptable because the Spanish law states that the environmental requirement can be reduced to $30 \%$ of the maximum habitat during drought conditions. Regarding water quality, dissolved oxygen concentrations during most summers are greater than $5.8 \mathrm{mg} / \mathrm{L}$. However, in dry years dissolved oxygen approaches $4 \mathrm{mg} / \mathrm{L}$. In these months, ammonium concentrations reach $1.95 \mathrm{mgNH}_{4} / \mathrm{L}$, which is acceptable because it is a punctual situation. The other constituents do not present serious problems for aquatic species.

We demonstrate that the OR maintains a greater habitat level while maintaining the demand reliability in this study. In some years, due to the application of the OR, the habitat values are reduced to between 55 and 80\%. However, these values still meet legislation. Some years have low autumn and winter inflows. Thus, the OR is activated. However, spring inflows may improve the situation and make the OR unnecessary.

\section{Assessment of Hydrological Alteration}

Site 4 is affected most by regulations due to its position below the city of Salamanca dams (Table 1). Under the PRESENT scenario, some indices indicate no relevant alterations (i.e., equal to or smaller than 10\%), including the Q5 to Q50 ratios and the mean monthly flow ranges. The same situation occurs for the percentage of months with zero flow (DL), which is null in these scenarios. These three aspects were maintained or even improved under the OR scenario with negligible Q5/Q50 alteration (1\%). Additionally, the standard deviation of mean monthly flows was altered very slightly, which was maintained in the OR scenario (-11 and $-13 \%$ in PRESENT and OR, respectively). Regarding the average flow conditions, some aspects had larger alterations, such as the variability among monthly and annual flows (+19 and $+31 \%$, respectively). However, the OR scenario provided larger variability in comparison with the PRESENT scenario. Thus, the changes in the river habitat were most likely not impaired. Because the baseline conditions should be matched as much as possible, the OR scenario was considered a relevant improvement in comparison to the PRESENT scenario. Specifically, the alteration was reduced to $-5 \%$ and $+25 \%$ in the CVintra and CVinter, respectively. The median (Q50) and mean annual discharge (MAdis) had an average alteration of $-31 \%$. In addition, the OR scenario improved the first of these indices by reducing it to $-23 \%$.

Regarding the low flow conditions, the three indicators showed alterations ranging from -30 to $-39 \%$. Under the PRESENT scenario, the average minimum monthly flows, the proportion of the minimum to the Q50 and the intensity of the droughts suggest intensified hydrologic stress in the river ecosystem. Specifically, the minimum flow was reduced from 6.64 to $4.05 \mathrm{~m}^{3} / \mathrm{s}$. However, the OR scenario improvement is dramatic in these aspects because the operation rules allowed the preservation of the original minimum flow and the drought intensity (IL) changed from 0.11 to 0.20 . Given that the Q50 reduction is approximately $-23 \%$, it is likely responsible for the changing Amin/Q50 ratio. The resultant IL alteration is $+90 \%$. Thus, because the Q95 increases, the droughts are less severe and have shorter durations. The high flow conditions suffer a certain degree of alteration under the PRESENT scenario. However, this alteration is smaller in magnitude than in the low flows. The average high flows would be reduced, whereas the other three indices would increase in relation to the baseline. The operation rules could reduce the alterations in terms of the flood intensity $(\mathrm{IH})$, but the high flow variability $(\mathrm{CVH})$ 
remains at $18 \%$ above the baseline situation. The ratio of the maximum flow to the Q50 showed a very small alteration of $+6 \%$. However, the Q50 reduction of $23 \%$ is affecting this result. Consequently this result does not show that these high flows are natural. In contrast, the high flow variability was clearly improved in comparison with the baseline conditions.

\section{CONCLUSIONS}

Water allocation in water resources systems is particularly important in the Mediterranean basins, especially when attempting to balance environmental demand and human activity uses. Here, we present a study which integrates three essential components that affect water allocation decisions in a methodological framework, including demands reliability, water quality and potential habitat for aquatic species. This process has been connected to three different models, including a resource sharing model, a water quality model for river reaches and reservoirs, and a habitat evaluation model. The joint application of these models allows managers and stakeholders to fully and comprehensively make decisions.

We present an improved general methodological framework here (ParedesArquiola et al. 2011) that implements a hydrological alteration assessment. This step evaluates water management scenarios. Thus, it could be used to evaluate stakeholder developed scenarios and future water management alternatives for various global change scenarios. This method could complement different methods to limit the hydrological alteration. For example, the ELOHA (Poff et al. 2010) or the Sustainability Boundary Approach (Richter 2010) methods could be used. However, these methods were initially developed for regions with scarce biological data and scientific resources.

This methodology was applied to the TRWS for the three previously mentioned problem types. From the application of this methodological framework, several conclusions were obtained. It was demonstrated that the optimization of the water management including the application of operation rules could improve the ecological conditions relative to the PRESENT scenario at point 4, with maximum water regulations. The OR scenario involved the application of the minimum flow according to the actual legal framework and the positive change in drought intensity (IL). Moreover, the variability of high flows was clearly improved relative to the baseline conditions. This improvement could benefit the river habitats and help the native fish species compete with the exotic fish species. Most of the indices (all but one) resulted in alterations equal to or smaller than $30 \%$ in the OR scenario (in positive and negative directions).

Furthermore, this methodological approach can improve the integration of the hydrological alteration assessment. Therefore, two potential improvements include the evaluation of management or climate-related scenarios in the DSS software (as presented here, either a priori or a posteriori) and the integrated optimisation of scenarios for minimum hydrological alteration. This approach, with previous evaluation, could be implemented as a framework for limiting hydrological alteration. In addition, this approach produces a set of sustainability boundary hydrographs (Richter 2010) that may limit the processes used in the methodology. The a posteriori evaluation could be implemented independently or as feedback in the software by integrating the hydrological alteration minimisation in the optimisation process. This method implies that rules are set to solve water right and legal condition conflicts. However, the hydrological indices are abundant and have considerable 
multicollinearity. Thus, it is necessary to select a small group of non-redundant indices (Olden \& Poff 2003) with ecological meaning for the river ecosystem. This selection was used previously in Mediterranean rivers (Belmar et al. 2011). In addition, improving the water management administrations adaptive management mechanisms for environmental flows is advised. Thus, independently of the applied method or technique, environmental flow regimes require monitoring and appraisal to provide feedback and improvements for river management. Regional scale modelling of the relationships between flow alteration and ecological response may be especially important for water management (Poff et al. 2010) and river restoration. This importance was recently demonstrated in Mediterranean rivers (Olaya-Marin 2012).

Acknowledgements This study was partially funded by the Spanish Ministry of Economy and Competitiveness and the SCARCE project (Consolider-Ingenio 2010 CSD2009-00065). We thank Diego García de Jalón for providing the environmental flow reports for the Tormes River Basin headwaters and Oscar Belmar for his support in assessing hydrological alterations.

\section{REFERENCES}

ACREMAN M. 2005. Linking science and decision-making: features and experience from environmental river flow setting. Environmental Modelling \& Software, 20, 99-109.

ANDREU, J., CAPILLA, J. \& FERRER, J. 1992. Modelo Simges de simulación de la gestión de esquemas de recursos hídricos, incluyendo utilización conjunta. Servicio de Publicaciones UPV.

ANDREU, J., CAPILLA, J., \& SANCHIS, E. 1996. AQUATOOL: A generalized decision support-system for water-resources planning and operational management. Journal of Hydrology, 177, 269-291.

ANDREU, J., SOLERA, A., PAREDES, J., PEREZ, M. A. \& PULIDO, M. 2008. RE: Decision support tools for policy making. Type to EUROPEAN WATER RESEARCH DAY.

BELMAR O., VELASCO J. \& MARTÍNEZ-CAPEL F. 2011. Hydrological classification of natural flow regimes to support environmental flow assessments in intensively regulated Mediterranean rivers, Segura River Basin (Spain). Environmental Management, 47, 992-1004.

BOVEE, K. D. 1982. A guide to stream habitat analysis using the Instream Flow Incremental Methodology. In: U.S. Department of the Interior (ed.) Fish and Wildlife Service Instream Flow Information Paper \#12. Washington D.C.

BOVEE, K. D., LAMB, J. M., BARTHOLOW, C. B., STALNAKER, J., TAYLOR, J. \& HENRIKSEN, J. 1998, Stream habitat analysis using the instream flow incremental methodology. In: U.S. Geological Survey (ed.) Biological Resources Division Information and Technology Report.

CAPRA H., PASCAL B. \& SOUCHON Y. 1995. A new tool to interpret magnitude and duration of fish habitat variations. Regulated Rivers: Research\& Management, 10, 281-289.

EC (EUROPEAN COMMISSION) 2000. Directive 2000/60/EC of the European Parliament and of the Council, of 23 October 2000, establishing a framework for Community action in the field of water policy. Brussels: Official Journal of the European Commission. 
GARCIA DE JALON D. \& LURUEÑA J. 2000. Estudio para la determinación de caudales mínimos en varios tramos de la cuenca del Tormes y del Alberche (provincia de Ávila). Technical Report of the Universidad Politécnica de Madrid for Junta de Castilla y León.

GLEICK, P. H. (ed.) 1993. Water in crisis: a guide to the world's fresh water resources, New York: Oxford University Press.

INFRAECO 2009. Estudio de Caudales Ecológicos en Masas de Agua Superficiales en la Demarcación del Duero. Fase 1: Evaluación del Hábitat Acuático en masas estratégicas. Rhyhabsim. Technical Report of the Universidad Politécnica de Madrid for Junta de Castilla y León.

SOLOMON, S., QIN, D., MANNING, M., CHEN, Z., MARQUIS, M., AVERYT, K. B., TIGNOR, M. \& MILLER, H. L. 2007. Contribution of Working Group I to the Fourth Assessment Report of the Intergovernmental Panel on Climate Change. In: INTERGOVERNMENTAL PANEL ON CLIMATE CHANGE (ed.) Climate Change 2007: The Physical Science Basis.

LAFAYETTE D. \& LOUCKS D. P. 2003. Developing habitat suitability criteria for water management: A case study. International Journal of River Basin Management, 4, 283-295.

LIU Y., GUPTA H., SPRINGER E. \& WAGENER T. 2008. Linking science with environmental decision making: Expriences from an integrated modeling approach to supporting sustainable water resources management. Environmental Modelling \& Software, 23, 846-858.

MARTINEZ-CAPEL F., HERNANDEZ MASCARELL A. B., PEREDO PARADA M., ALCARAZ HERNANDEZ J. D., GAROFANO GOMEZ V. \& OROZCO GONZALEZ A. A. 2006. Validació biològica del règim de cabals de manteniment definits al pla sectorial de les conques internes de Catalunya en 10 trams fluvials. Technical report of the Universidad Politécnica de Valencia for the Agència Catalana de l'Aigua (Generalitat de Catalunya).

MILHOUS, R. T., BARTHOLOW, J. M., UPDIKE, M. A. \& MOOS, A. R. 1990. Reference Manual for Generation and Analysis of Habitat Time SeriesVersion II. In: UNITED STATES FISH AND WILDLIFE SERVICE (ed.). Washington D.C.

MARM (MINISTERIO DE MEDIO AMBIENTE, MEDIO RURAL Y MARINO) 2008. Orden ARM/2656/2008, de 10 de septiembre, por la que se aprueba la instrucción de planificación hidrológica. Madrid: Boletín Oficial del Estado.

NRC (NATIONAL RESEARCH COUNCIL) 2000. New strategies for America's watersheds. In: NATIONAL ACADEMIC PRESS (ed.). Washington D.C.

PARASIEWICZ, P. 2008. Habitat time series analysis to define flow augmentation strategy for the Quinebaug River, Connecticut and Massachusets, USA. River Research and Applications, 24, 453-458.

PAREDES, J., SOLERA, A. \& ANDREU, J. 2004. Modelo Gescal para la simulación de la calidad del agua en sistemas de recursos hídricos. Manual de usuario. Servicio de Publicaciones UPV.

PAREDES, J., ANDREU, J. \& SOLERA, A. 2010. A decision support system for water quality issues in the Manzanares River (Madrid, Spain). Science of the Total Environment, 408, 2576-2589.

PAREDES-ARQUIOLA, J., ANDREU-ALVAREZ, J., MARTIN-MONERRIS, M. \& SOLERA, A. 2010. Water quantity and quality models applied to the Jucar River Basin, Spain. Water Resources Management, 24, 2759-2779. 
PAREDES-ARQUIOLA, J., MARTINEZ-CAPEL, F., SOLERA, A. \& AGUILELLA, V. 2011. Implementing environmental flows in complex water resources systems - case study: the Duero river basin, Spain. River Research and Applications, Published online in Wiley Online Library.

OLAYA-MARIN, E. J., MARTINEZ-CAPEL, F., COSTA, R. M. S. \& ALCARAZHERNANDEZ, J. D. 2012. Modelling native fish richness to evaluate the effects of hydromorphological changes and river restoration (Júcar River Basin, Spain). Science of the Total Environment, 440, 95-105.

OLDEN, J. D. \& POFF, N. L. 2003. Redundancy and the choice of hydrologic indices for characterizing stream flow regimes. River Research and Applications, 19, 101-121.

POFF, N. L., ALLAN, J. D., BAIN, M. B., KARR, J. R., PRESTEGAARD, K. L., RICHTER, B. D., SPARKS, R. E. \& STROMBERG, J. C. 1997. The Natural Flow Regime. Bioscience, 47, 769-784.

POFF, N. L., RICHTER, B. D., ARTHINGTON, A. H., BUNN, S. E., NAIMAN, R. J., KENDY, E., ACREMAN, M., APSE, C., BLEDSOE, B. P., FREEMAN, M. C., HENRIKSEN, J., JACOBSON, R. B., KENNEN, J. G., MERRITT, D. M., O'KEEFFE, J. H., OLDEN, J. D., ROGERS, K., THARME, R. E. \& WARNER, A. 2010. The ecological limits of hydrologic alteration (ELOHA): a new framework for developing regional environmental flow standards. Freshwater Biology, 55, 147-170.

RICHTER, B. D. 2010. Re-thinking environmental flows: from allocations and reserves to sustainability boundaries. River Research and Applications, 26, 1052-1063.

TDWR (TEXAS DEPARTMENT OF WATER RESOURCES) 1982. Multireservoir simulation and optimization model SIM-V. Program Documentation and User's Manual.

UNCED (UNITED NATIONS CONFERENCE ON ENVIRONMENT AND DEVELOPMENT) 1992. Chapter 18. Protection of the Quality and Supply of Freshwater Resources: Application of Integrated Approaches to the Development, Management and Use of Water Resources. In: UNITED NATIONS (ed.) Agenda 21. Rio de Janeiro. 


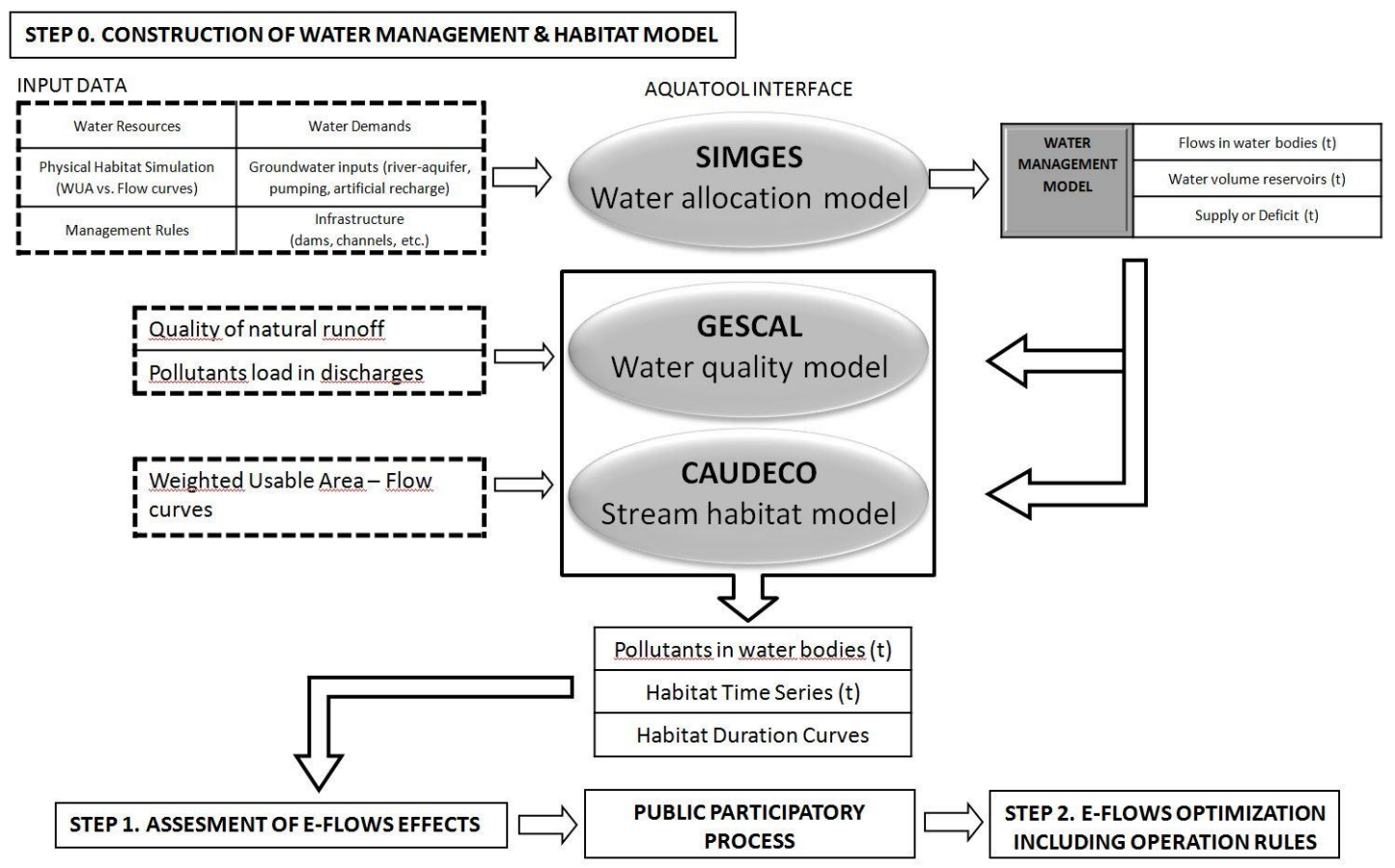

Figure 1. Scheme of the methodological framework applied for coupling the habitat simulation, environmental flows, and water resources management at basin scale, based on the general scheme by Paredes-Arquiola et al. (2011).

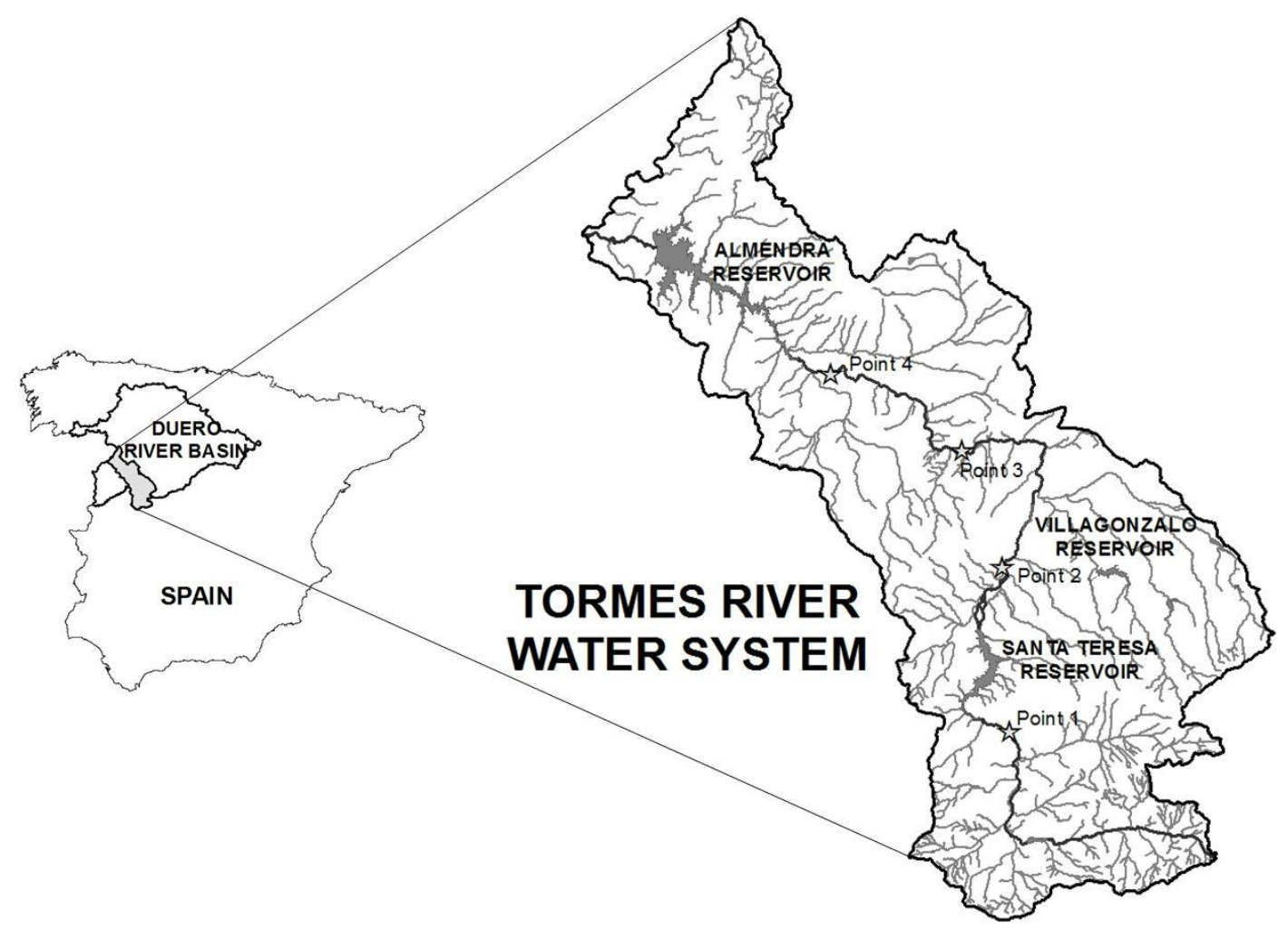

Figure 2. Location of the Duero River basin in the Spanish Iberian Peninsula, with a detail of the Tormes River Basin. 


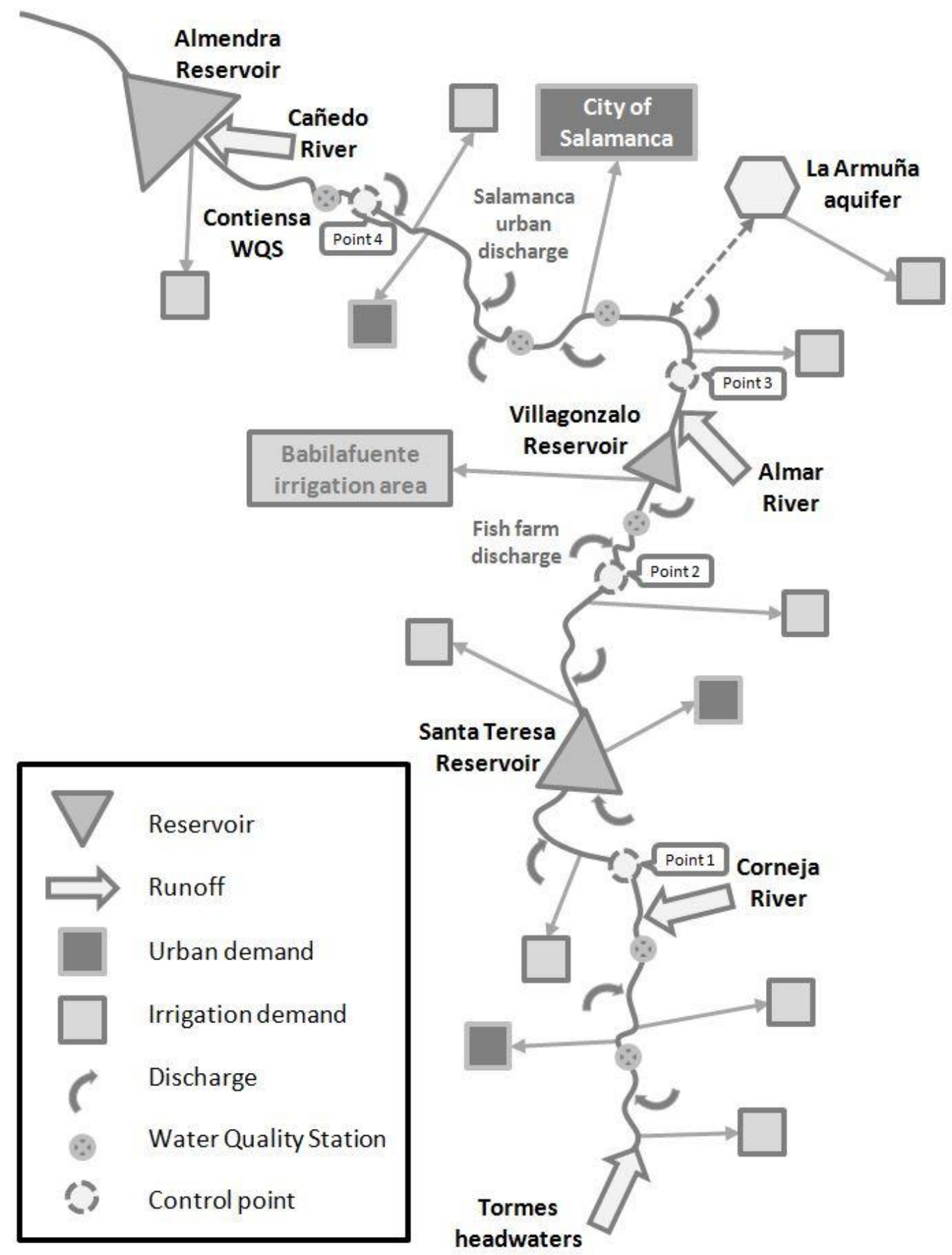

Figure 3. Simplified scheme of the Tormes River Water System. 


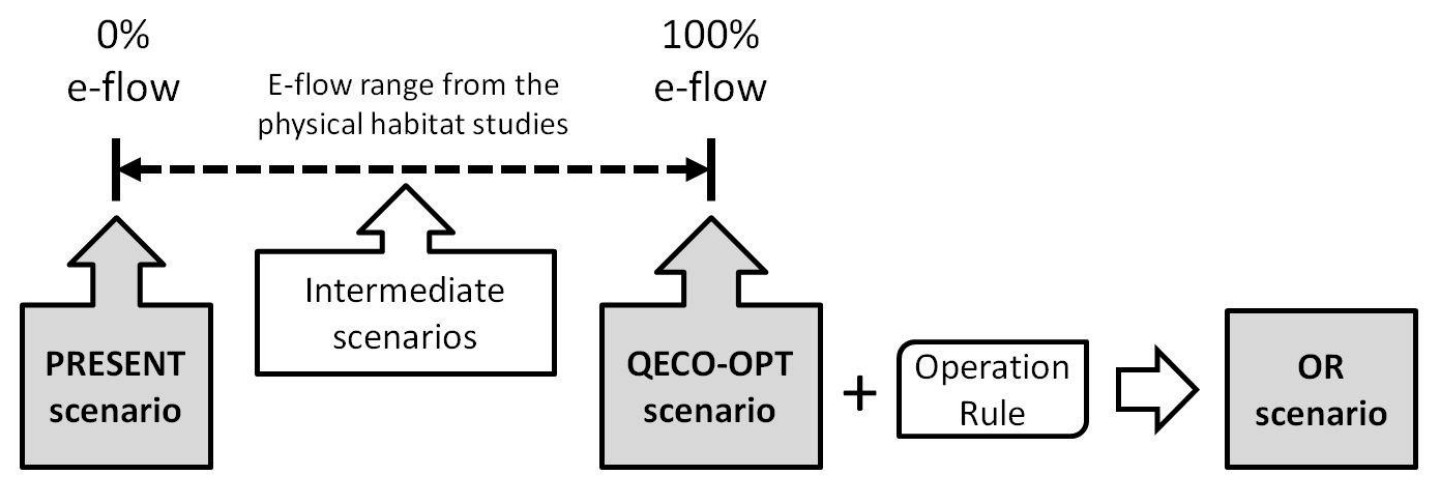

Figure 4. Scheme of simulations.

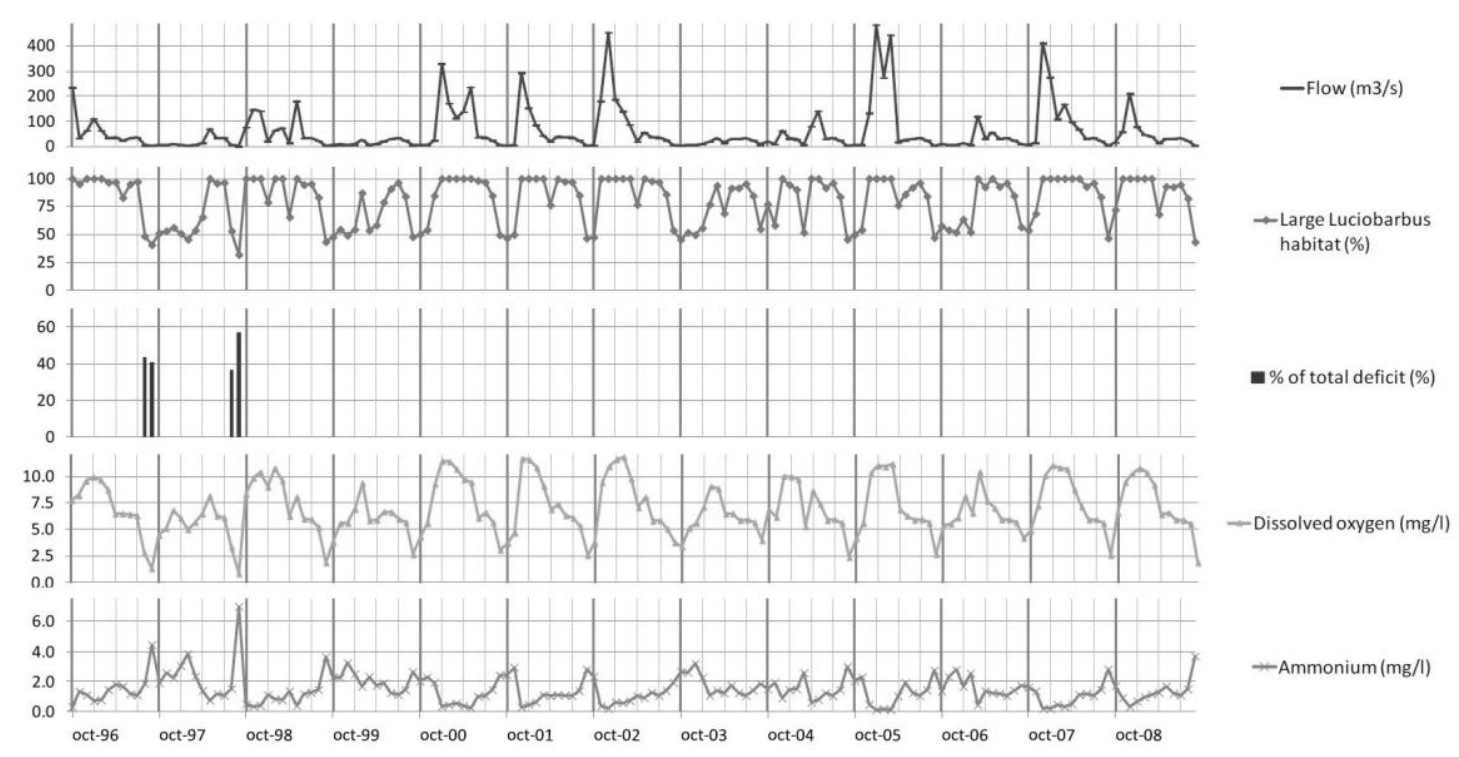

Figure 5. Simulation-Indicators for the PRESENT scenario at point 4. The river flow is indicated, together with the indicators regarding fish habitat, deficit of supply for irrigation and water quality.

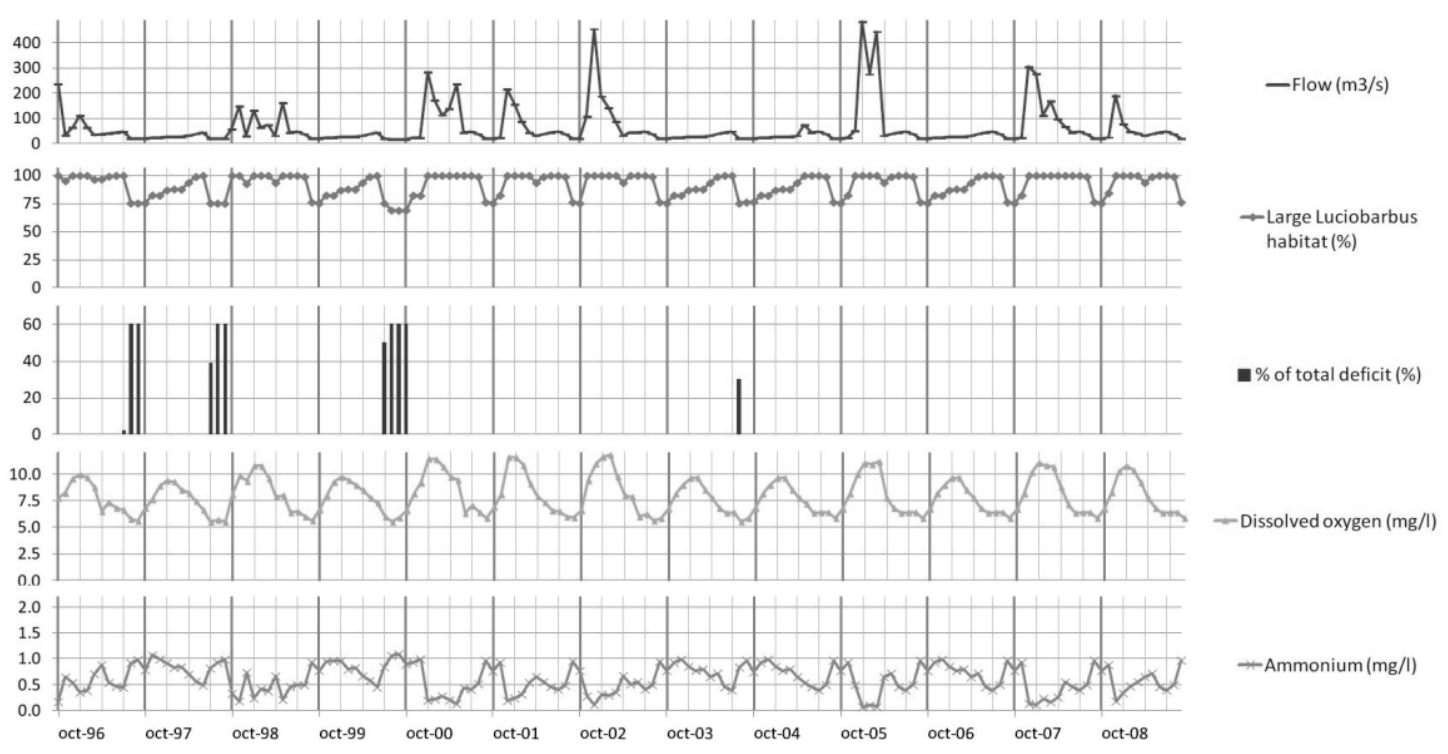


Figure 6. Simulation-Indicators for the QECO-OPT scenario at point 4. The river flow is indicated, together with the indicators regarding fish habitat, deficit of supply for irrigation and water quality.

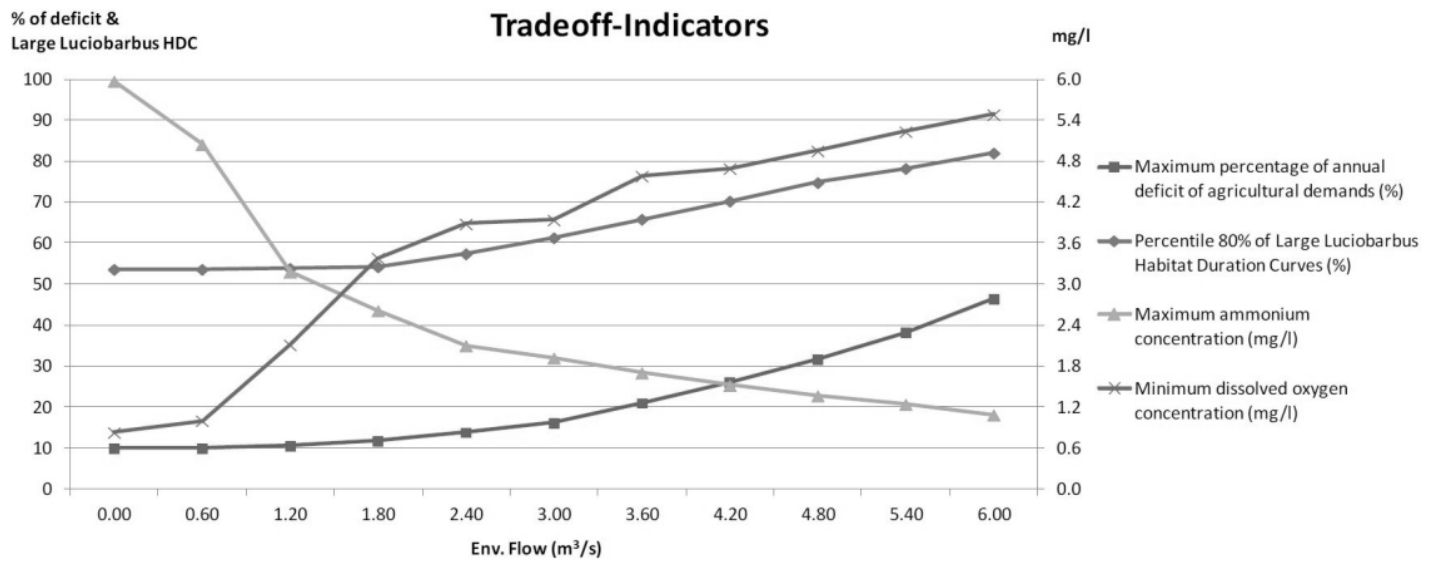

Figure 7. Tradeoff-Indicators in function of the minimum environmental flows (September) at point 4 (downstream of Salamanca). The indicators integrate agricultural demands, fish habitat and water quality; this chart supports decision making and the public participatory process.

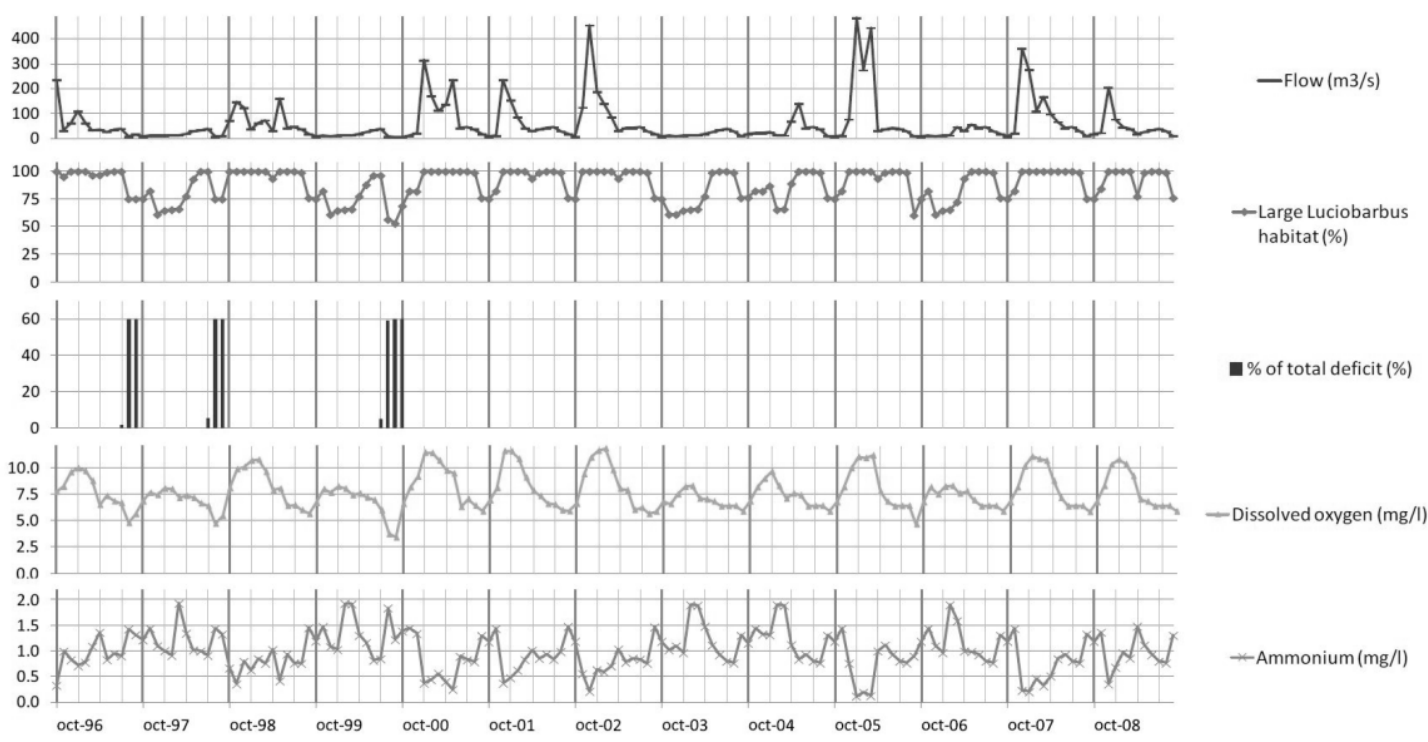

Figure 8. Simulation-Indicators for the scenario with operating rules $-\mathrm{OR}-$ at point 4 . The river flow is indicated, together with the indicators regarding fish habitat, deficit of supply for irrigation and water quality. 


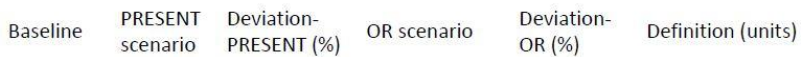

\begin{tabular}{|c|c|c|c|c|c|c|}
\hline & & scenario & PRESENT (\%) & & $\mathrm{OR}(\%)$ & \\
\hline \multicolumn{7}{|c|}{ Average flow conditions } \\
\hline Q5/Q50 & 1.82 & 2.00 & 10 & 1.84 & 1 & $\begin{array}{l}\text { Percentile } 95 \% \text { of the mean monthly flows divided by the median } \\
\text { annual flow (dimensionless) }\end{array}$ \\
\hline Q50 & 30.18 & 21.27 & -30 & 23.34 & -23 & Median annual flow $\left(\mathrm{m}^{3} / \mathrm{s}\right)$ \\
\hline Range & 45.49 & 41.48 & -9 & 40.75 & -10 & Maximum annual discharge minus minimum annual discharge $\left(\mathrm{m}^{3} / \mathrm{s}\right)$ \\
\hline SD & 15.76 & 14.03 & -11 & 13.78 & -13 & Standard deviation of annual discharge $\left(\mathrm{m}^{3} / \mathrm{s}\right)$ \\
\hline CVintra & 0.60 & 0.72 & 19 & 0.57 & -5 & Coefficient of variation of mean monthly flows (dimensionless) \\
\hline CVinter & 0.47 & 0.62 & 31 & 0.59 & 25 & Coefficient of variation of mean annual flows (dimensionless) \\
\hline MAdis & 33.44 & 22.70 & -32 & 23.36 & -30 & Mean annual flow $\left(\mathrm{m}^{3} / \mathrm{s}\right)$ \\
\hline \multicolumn{7}{|c|}{ Low flow conditions } \\
\hline ML 13 & 6.64 & 4.05 & -39 & 6.63 & 0 & Mean of the mean minimum monthly flows for all months $\left(\mathrm{m}^{3} / \mathrm{s}\right)$ \\
\hline Amin/Q50 & 0.42 & 0.27 & -36 & 0.30 & -28 & Minimum annual flow divided by Q50 (dimensionless) \\
\hline IL & 0.11 & 0.07 & -30 & 0.20 & 91 & $\begin{array}{l}\text { Drought intensity: Monthly flow equalled or exceeded } 95 \% \text { of the } \\
\text { time divided by mean annual flow (dimensionless) }\end{array}$ \\
\hline \multicolumn{7}{|c|}{ Duration of low flow } \\
\hline $\mathrm{DL}$ & 0.00 & 0.00 & 0 & 0.00 & 0 & Percentage of months with average zero flow (dimensionless) \\
\hline \multicolumn{7}{|c|}{$\underline{\text { High flow conditions }}$} \\
\hline MH 13 & 94.58 & 80.90 & -14 & 81.09 & -14 & Mean of the mean maximum monthly flows for all months $\left(\mathrm{m}^{3} / \mathrm{s}\right)$ \\
\hline Amax/Q50 & 1.93 & 2.22 & 15 & 2.05 & 6 & Maximum annual discharge divided by Q50 (dimensionless) \\
\hline IH & 3.25 & 4.06 & 25 & 3.77 & 16 & $\begin{array}{l}\text { Flood Intensity: Monthly flow equalled or exceeded } 5 \% \text { of the time } \\
\text { divided by mean annual flow (dimensionless) }\end{array}$ \\
\hline CVH & 0.68 & 0.81 & 20 & 0.80 & 18 & $\begin{array}{l}\text { Coefficient of variation in mean maximum monthly flows } \\
\text { (dimensionless) }\end{array}$ \\
\hline
\end{tabular}

Table 1. Definitions of the hydrological alteration indices and results at point 4 (Contiensa WQS), under the baseline conditions (near natural) and two scenarios of water management, the actual situation -PRESENT- and optimization with operating rules -OR-, with their correspondent percentages of hydrological alteration in each of the indices. 